\title{
Functional Traits and Adaptation Mechanisms of Eucalyptus Species in the Congo
}

\author{
Chrissy Garel Makouanzi Ekomono ( $\nabla$ garelmak@yahoo.fr ) \\ Universite Marien Ngouabi https://orcid.org/0000-0003-0920-5216 \\ Castella bath Shéba Vitel Loubassou \\ Institut National de Recherche Forestière \\ Mavie Parfait Mbama \\ Pronar \\ Grace Jopaul Loubota Panzou \\ University of Exeter \\ Philippe Vigneron \\ CIRAD Departement Systemes biologiques
}

\section{Research}

Keywords: Adaptation, Environment change, Eucalyptus, Functional traits, Clustering analysis.

Posted Date: August 25th, 2020

DOI: https://doi.org/10.21203/rs.3.rs-64174/v1

License: @ (1) This work is licensed under a Creative Commons Attribution 4.0 International License. Read Full License 


\section{Abstract}

Background: Adaptation is not only effective by considering the survival of plants, but also by taking into account the traits that support adaptation to environmental changing. Local adaptation occurs because different environmental factors impose different selective pressures across habitats. Understanding the ecophysiological mechanisms underlying survival and growth in plants is crucial for establishing the reasons trade-offs are associated with adaptation.

Methods: A comparison provenance test of 29 species of Eucalyptus were used to understand the adaptation strategies on the coastal plains of Pointe-Noire, in the Republic of the Congo. Survival, growth traits and leaves functional traits was jointly measured. Climatic traits of the species origin areas were also studied. Cluster analysis was performed to group species according to their growth strategy.

Results: The results suggest that species would be able to survive under current environmental change by adjusting their specific leaf area plasticity. The cluster analysis suggests a subdivision of the 29 species into four groups. The first cluster brings together E.pilularis and E.peltata, with the lowest growth and the lowest specific leaf area. This cluster contains two species totally unsuited to the local conditions of Pointe-Noire. The second cluster contains species with a wide variety of responses as to their growth strategy, and are able to adapt to the local conditions. The third cluster includes a species are specialized in acquiring high proportions of resources while investing very little in growth. The fourth cluster groups the species with a very slow strategy of acquiring and using resources. Leaf anatomy is quite responsive to climatic conditions.

Conclusion: By evaluating all aspects of strategies, Eucalyptus species have shown great variation in their functionnal traits and this may explains their diverse ecological range.

\section{Introduction}

The predictions reports that Africa will be most impacted by climate changes and there is a significant risk of exceeding the adaptive capacity of many forest ecosystems for the supply of vital goods and services (FAO 2015). The possible impact of climate change on genetic diversity and the adaptive potential of species is a question currently being asked. However, the experimental data to be able to answer this question is lacking in the current state. In the face of global climate changes, it is necessary to adapt species to new environments (Hamrick 2004, Jump and Peñuelas 2005, Franks and Hoffmann 2012) and to understand the biological processes that drive this adaptation (Loo et al. 2011). Understanding the basis of adaptation remains a dauting task. Understanding of the capacity of species to adapt will become important for directing conservation and management of biodiversity (Dillon et al. 2014). It is therefore important to consider environmental factors to understand which ones determine the reactions (Evans et al. 1985). The study of functional traits has a long tradition in ecological studies, especially with regard to plants (Vandewalle et al. 2010). The need to understand the unprecedented changes in ecosystems, which are influenced by environmental changes, has given a way to understanding the morphological, physiological, phenological characteristics, which represent ecological strategies and determine how plants react to environmental factors (Pérez-Harguindeguy et al. 2013).

Functional traits indicate the ability of a plant to acquire, use and conserve resources (Westoby et al. 2002, Reich et al. 2003). The plasticity of these functional traits is an important source of the phenotypic variation observed in the introduced populations. It allow introduced species to succeed under the new conditions, without a diversity of DNA (Drenovsky et al. 2012). It is recognized that biodiversity remains essential to humanity and that genetic diversity within and among stands is the pivot, both of current and future development of forestry (Kremer 2000). We can hope that this diversity includes also a significant proportion of elements of interest for the survival and adaptation of species (Kremer 2000).

Adaptation to different environmental conditions results in costly fitness trade-offs (Hereford 2009; Vanwallendael et al. 2019). Assisted migration of individuals or populations of a species are recognized as a potentially important means of responding to climate change. However, this approach is not yet widely used (FAO 2014). 
Eucalyptus have remarkable plasticity, generally attributed to selection pressures that have kept them in environments with high constraints throughout their evolution, especially on soils poor in nutrients (Cossalter et al. 1999, Epron et al. 2007), and in hot and arid areas (Booth 2012).

It is well known that certain species are more apt than others to grow in poor soils, but so far, there has been very little study of the physiological bases of this difference in behavior.

The first attempts to introduce eucalyptus began in 1953 in the Congo, and then several species and provenances trials was made. Several studies have been carried out on the productivity of these introduced species, at the end of which certain species have proved to be adapted to local conditions, others not (Groulez 1964). However, the ecophysiological mechanisms explaining these responses have not been studied in Congo.

This present study aims to understand the adaptation mechanisms of 29 eucalyptus species using ecophysiological approach. We addressed three research questions: (i) do functional traits vary among eucalyptus species at different ages? (ii) what tradeoffs can be found among functional traits? (ii) is there a potential adaptation of eucalyptus species using relationships between functional traits and climatic variables?

The combined study of these functional traits will make it possible to characterize more fully the functioning of the plant and to highlight adaptive strategies of the different species as suggested by Laclau et al. (2016). The species comparative study of adaptive, growth, climate and functional traits and their correlations in the 29 species will therefore allow a description of the general trends explaining the physiological mechanisms linked to their local adaptation.

\section{Material And Methods}

\section{Study site and sampling}

The present study is based on data collected from a provenance trial established at the Kissoko forestry station ( $4^{\circ} 45^{\prime} 51^{\prime \prime} \mathrm{S}$, $\left.11^{\circ} 59^{\prime} 21^{\prime \prime} \mathrm{E}\right)$, in the southern of Republic of Congo. Mean annual rainfall is around to $1200 \mathrm{~mm}$; daily temperature is around $25-26^{\circ} \mathrm{C}$ in the rainy season (from October to May) and around $22-23^{\circ} \mathrm{C}$ in the dry season (from June to September) (Jamet and Rieffel 1976). Relative humidity is high (85\%) with low seasonal variability (2\%). The soil belonged to the ferralitic class, highly desaturated in bases (Nzila 2001).Fieldwork was mostly carried out in four blocks randomly established in a 1.71 ha experimental site. Each block contained 32 juxtaposed plots, and each plot had nine trees. There were 800 trees per hectare with spacing among trees of $4.7 \mathrm{~m} \times 2.65 \mathrm{~m}$. Based on this systematic sampling, we gathered data on 29 eucalyptus tree species belonging to 8 genera and (Supporting information Table 1). This plantation came from seeds that have been harvested in several parts of Australia (from the North, North East, East and South East coasts of the continent) and Indonesia in cool and humid climates, as well as in dry and hot areas (Figure 1).

\section{Tree measurements}

Two different ages (14 and 54 months) have been considered for the tree measurements after evaluating species survival rate. For each tree, we were performed non-destructive quantitative measurements including collar circumference, total height and leaf measurements. Collar circumference ( $\mathrm{CC}$ in $\mathrm{cm}$ ) was measured with a tape the trunk base. Total tree height $(\mathrm{HT}$ in $\mathrm{m})$ was measured with a VERTEX IV dendrometer at a distance that was approximately equivalent to tree height. Leaf variables including specific leaf area (SLA), leaf thickness (LT) and leaf density (LD) were measured by 10 leaves of each tree that were harvested from the upper and lower crown. These 10 leaves were chosen as adult, neither juvenile nor senescent with a complete expansion of the blade, free from any attack by pathogens. Leaf tthickness was measured immediately after leaf removal with a digital micrometer Mitutoyo at a point mid-way along the length of the leaf and mid-way between the median and the edge of the leaf. Leaves area were measured in laboratory after their scan and then using MatLab software for image processing.These leaves were dried at $65^{\circ} \mathrm{C}$ to constant weight. The dry weight was used in conjunction with their measured area to calculate specific leaf area $\left(S L A\right.$ in $\left.\mathrm{m}^{2} . \mathrm{kg}^{-1}\right)$ by the following formula: 
$S L A=\frac{\sum_{i}^{n} S i}{\sum_{i}^{n} M i}$

Where $S_{i}, M_{i}$ and $n$ are respectively the leaf area, the leaf dry mass and the number of leaf harvested.

The leaf density (LD in kg. $\mathrm{m}^{-3}$ ) was calculated considering SLA and LT (Sefton et al. 2002):

$$
L D=\frac{1}{(S L A \times L T)}
$$

\section{Climate data}

Using meteorological stations informations (http://www.bom.gov.au/) of each site where the eucalyptus species were collected in Australia and Indonesia, 18 climatic variables were considered in this study: 1- Average annual rainfall (AAR), 2- Maximum annual rainfall (MAR), 3- Minimum annual rainfall (mAR), 4- Maximum monthly average rainfall (MMAR), 5- Minimum monthly average rainfall (mMAR), 6- Number of months of rainfall less than $50 \mathrm{~mm}$ (NR50), 7- Average annual temperature (AAT), 8Maximum monthly temperature (MMT), 9- Minimum average temperature (mMT), 10- Maximum monthly average temperature (MMAT), 11- Minimum monthly average temperature (mMAT), 12- Number of days below $40^{\circ} \mathrm{C}$ (ND40), 13- Number of freezing days (NFD), 14- Potential evapotranspiration (PE), 15- Solar radiation (SR), 16- Altitude (A), 17- Longitude (Long), 18- Latitude (Lat).

\section{Statistics analysis}

The following linear mixed model was used to perform ANOVA for functional traits, then survival rate and growth:

$$
y=1 \mu+X_{b} b+Z_{s b} s b++Z_{s p} s p+Z_{p l o t} p l o t+\varepsilon
$$

Where $y$ is the vector of response variable; $\mu$ is a the overall mean; $X$ and $Z$ are the design matrix connecting respectively the fixed and random effects to the data; $b$ is a vector of fixed effects due to the blocks; $s b \sim N\left(0, \sigma^{2} s b l d\right)$ is a vector of random subgenus effect, $\sigma^{2} s b$ being the variance related to subgenus effect, Id is the identity matrix; $s p \sim N\left(0, \sigma^{2} s p l d\right)$ is a vector of random specie effect, $\sigma^{2}$ sp being the variance related to specie effect; plot $\sim \mathrm{N}\left(0, \sigma^{2}\right.$ plotld $)$ is a vector of random spatial environmental effects due the plot, $\sigma^{2}$ plot being the variance related to spatial effect, $\varepsilon \sim N\left(0, \sigma^{2} \varepsilon l d\right)$ is a vector of residual effect. Before performing ANOVA on survival rate, an angular arc sinus transformation.

$$
p^{\prime}=\arcsin \sqrt{p}
$$

Where $p^{\prime}$ is the transformed value of survival rate, $p$ is the original value of survival rate.

To detect the covariations among functional traits, we used pairwise Pearson's multiple correlation tests to bivariate relationships.A principal component analysis was performed in order to identify the similarities between the climatic characteristics of the species origin areas and those of introduction area.At species level, funtional traits were estimated from the tree measurements at 14 and 54 months (Supporting information Table S1). The K-means partitioning method was performed to assign observations to clusters concerning growth and functional traits at 54 months.All statistical analyses were performed within the open-source R environment (R Core Team, 2019; version 4.0.2).

\section{Results}

\section{Survival}


At 15 and 54 months, the survival rate of the species is significant different between subgenera (Pvalue $=0.0003$ and $<.0001$ ) and between species (Pvalue $<0.001$ and $<.0001$ ). The subgenera Blakella and Idiogenes are the most represented with survival rates of $91 \%$ and $87 \%$ respectively, while the subgenera Eucalyptus and Eudesmia are poorly represented with survival rates of $35 \%$ and $13 \%$ respectively (Figure 2). A less survival of the species E.tetrodonta (17\%), E.peltata (12\%) and E.pilularis (0\%) was noted at 54 months. E. Tereticornis (94\%) and E.Tesselaris (88\%) have the highest survival rates (Figure 2).

\section{Growth and Ecophysiological traits}

Growth traits naturally increase with age between 15 and 54 months. The Anova showed significant differences between species of the same subgenus as well as between subgenera for the all traits (Table 2). Among the functional traits, only leaf thickness remained almost stable between 15 and 54 months, while specific leaf area increase and leaf density decrease. The subgenera Symphyomyrtus, Idiogenes, Eucalyptus and Corymbia show greater variations in LT, however their SLA remains weak. This trend is different for the subgenera Minutifructus, Eudesmia, Blakella and Alveolata, wich show strong SLA and weak LT. The Flores provenance of E.urophylla shows one of the best growths and therefore a strong SLA.

\section{Correlations}

The juvenile-adult correlations (Figure 3) indicate a fairly close ranking at different ages for LT and height. On the other hand, the LD ranking changed completely between 15 and 54 months $(r=0)$. There is naturally a strong and positive relation between height and collar circonférence ( $r=0.79$ and 0.84$)$. However, there is a moderate and positive correlation between growth and survival ( $r=0.41$ to 0.57 ). Between ages the SLA correlation is moderate $(r=0.49)$. Between growth and SLA the correlation is low. A negative correlation is noted between SLA and LD as well as LT. LD and LT vary in opposite sens.

\section{PCA and clustering analysis}

The PCA results indidicate that the main component represents $65.60 \%$ of the whole of variance (Figure 4). The two main components are respectively associated with temperatures for the first (40.76\%) and rainfull for the second (24.84\%). The results shows (Figure 5) that species such as E.tereticornis, E.nesophilla, E.tetrodonta, E.polycarpa, E.brassiana, E.alba are found in areas with similar characteristics to those of the Congolese coastal savannas. On the other hand, the climatic conditions of the areas of species line E.punctata, E.maculata, E.acmenoides, E.resinifera is different from those of the introduction area.

The cluster analysis suggests a subdivision of the 29 species into four groups (Figure 6). The first cluster brings together E.pilularis and E.peltata, with the lowest growth and the lowest SLA. We note that at the end of this experiment, no individuals representing E.pilularis were present in the trial. The second cluster contains species with a wide variety of responses as to their growth strategy. We meet species with very high growth and high SLA. This is the case, for example, of E.cloeziana, E.urophylla_Flores and E.alba_Timor. This cluster also includes species with medium growth and low SLA like E.robusta and E.brassiana. Species like E.toreliana with low growth and large SLA are part of this cluster. The species grouped within cluster 3 have exclusively a large SLA but weak growth. The last cluster groups together the species with weak growth and weak SLA.

\section{Discussion}

\section{Plant survival}

Survival is a first fundamental criteria for the adaptation of species (Gardner 2017). Plants compete for light, water, nutrients, air and space to survive. The ranking of species according to their survival rate does not considerably change between 15 and 54 months. The total disappearance of the E.pilularis plants at 54 months reflects a very poor adaptation to the local conditions of Pointe-Noire. This result corroborates those obtained by Brezard (1982) in the same region. However, species with a low survival rate but good growth like E.citriodora are not inadapted. They must have been influenced by several factors like density plantation leading to competition between species. Intense competition between adjacent plots would have accentuated 
differences between fast-growing and slow-growing species, through suppression of the slower growing species (Hunde et al. 2007)

Therefore adaptations can be divided into two general categories: functional adaptations, which are adaptations that help an organism survive in its environment, and growth and reproductive adaptations, which are adaptations that help an organism successfully growth and reproduce. An organism must have both adaptations in order to ensure the « total adaptation ».

\section{Traits evolution and correlations}

All the growth traits evolved positively between 15 and 54 months. The stability of leaf thickness and the decrease in leaf density led to an increase in SLA between these two ages. We can evoke to explain the result that at 15 months water was a limiting factor, while it became less at 54 months with root development favoring a larger area of prospecting, but also in depth. It was noted a decrease in the average annual temperature from $27^{\circ} \mathrm{C}$ to $24.9^{\circ} \mathrm{C}$ between the leaf samples harvest between 15 and 54 months. When the temperature decreases, the plants develop a large leaf area in order to maximize the capture of light (Killi et al. 2017). Our results show negative and significant correlations between SLA, LT and LD. These results corroborate those of Vile et al. (2005) and Niinemets (1999). Low SLA due to thicker and/or denser leaves contributes to leaf life span, nutrient retention, and protection against desiccation (Ackerly et al. 2002). The correlations between height and functional traits allow us to realize the acquisition and use of resources strategies of different species. A weak positive correlation was noted between height and SLA. Species with a large SLA generally have good growth because they maximize their photosynthetic capacity. The weak correlation observed between these two traits is explained by the existence of species with a large SLA but with low growth.

\section{Adaptive species strategies}

The knowledge of climate similarity, as well as knowledge of locally favored adpative traits can help to inform plantation strategies (Wright et al. 2018). It was assumed that species from areas with climatic conditions close to those of Pointe-Noire should be better suited compared to those from remote areas. This hypothesis has been verified only for one specie, E.tereticornis having a good balance between the acquisition and the use of resources. While some species from areas not similar to Pointe-Noire appear to be more suitable, as is the case for most of the species grouped within cluster 2. These species thrive well in humid or sub humid, tropical or subtropical regions under rainfall of 1100 to $1500 \mathrm{~mm}$ with a dry season of 1 to 5 months. A similar rainfall regime is encountered in the Congo. The adaptations of eucalypts, which allow many species to grow successfully under often difficult conditions of poor soils and highly variable rainfall, have provided some of the characteristics that make a small number of eucalypt species particularly successful in plantations (Booth 2012). In species, genetic diversity contains a significant proportion of elements of interest for the survival and adaptation of species. Some individuals have genes that allow them to respond better to environmental constraints, which gives them better adaptive value than their peers (Bradshaw and Christina 2006, Savolainen et al. 2013). Genetic variations can therefore modulate the local effects of environmental change (Parmesan 2006). Local adaptation can be constrained by variation in natural selection and gene flow (Kawecki and Ebert 2004, Leimu and Fischer 2008, Bamba et al. 2018). Studies have revealed that local adaptation among provenances and populations of E.camaldulensis has been suggested from variation in adaptive phenotypes which correspond to local environment including: morphological traits (growth form, leaf thickness, stomatal density and phenology) (James and Bell 1995); growth rate (Otegbeye 1985); wood properties (El-Lakany 1980); physiological responses (Morshet 1981) and drought tollerance (Lemcoff et al. 2002). The adaptive clines suggested from phenotypic variation are supported by evidence of genetic adaptation within coding genes (Thumma et al. 2012).

Leaf traits do not vary randomly, but are constrained by trade-offs from investing carbon in leaves (Wright et al. 2004). Specific leaf area is an important plant functional trait as it is an indicator of relative growth rate, stress tolerance and leaf life span. It is generally assumed that intraspecific variation of SLA is mostly the result of environmentally induced phenotypic plasticity (Liu et al. 2017), but genetic effects may also be present, due to local adaptation or genetic drift (Scheepens et al. 2010). At the interspecific level, functional traits can be used to explain community composition and structure (Lavorel and Garnier 2002; Díaz et al. 2004). Functional traits can also be used to classify plant species according to Grime (1977) strategies or to explain 
the occuérrence and distribution of species (Díaz et al. 1998). The present results suggest that populations of differents species would be able to survive under current change in environmental conditions by adjusting their SLA plasticity. This adjustment by means of phenotypic plasticity may allow populations in the long run to adapt genetically to the environmental changes via genetic assimilation (Price et al. 2003). The classification of species shows that the first cluster contains two species totally unsuited to the local conditions of Pointe-Noire. The species grouped at second cluster are able to adapt to the local conditions of Pointe-Noire, through a great plasticity of their specific leaf area. There are species with a rapid resource acquisition and development strategy. However, there are also species with a slow acquisition strategy but a rather efficient development of resources. We would place the third cluster species in the field of rapid resource acquisition strategies and a slow return on investment on Wright's leaf economic spectrum (2004). According to Lambers and Poorter (1992), these species are specialized in acquiring high proportions of resources (water, light, carbon) while investing very little in growth. Finally, the fourth cluster groups together the species with a very slow strategy of acquiring and using resources. This results in poor growth due to their reduced photosynthetic capacity.

\section{Conclusion}

Research in ecophysiology has improved the understanding of tree adapation by adressing functional traits that play a critical role in adaptation (Bouvet et al. 2020). From the interpretation of ecophysiological traits and growth, four major groups emerge: (i) species with a large SLA, which gives them a high photosynthetic capacity, with a good growth; (ii) species having a low SLA with poor growth due to their reduced photosynthetic capacity, so insuitable to our local conditions; (iii) efficient species with low SLA and very good growth; (iv) species with large SLA and poor growth. The species in-group (ii) and (iv) are the least suitable. Those of group (iv) maximize the capture of resources but do not have good growth. This present study offers interesting perspectives, in particular: the study of the differential expression of genes of different species installed in different environmental situations; the implementation of multi-site comparative tests of species in order to take into account the microenvironmental heterogeneity; a comparative study of the strategies for acquiring and using the resources of the different species in their original area and in the area of introduction. The combination of both phenotypic and genomic approach (Steane et al. 2017) must be taken into account in future studies of plant adaptation to Congo local conditions.

\section{Declarations}

Acknowlegments : We are grateful to Pacifique Ntadi and CRDPI technical team for field help.

Authors' contributions: PhV and CGME conceived and designed the experiments. CBSVL and MPM performed the experiments. CGME analyzed the data. CGME took the lead in writing the manuscript and all authors provided critical feedback.

Funding : This study has been supported financially by Conservation Action Research Network (CARN) of Congo Bassin Forest Partneship (CBFP).

Availability of data and materials : The datasets used and/or analysed during the current study are available from the corresponding author on reasonable request.

Competing interests : The authors declare no conflict of interest.

\section{References}

1. Ackerly D, Knight C, Weiss S, Barton K and Starmer K (2002) Leaf size, specific leaf area and microhabitat distribution of chaparral woody plants: contrasting patterns in species level and community level analyses. Oecologia 130 (3): $449-457$.

2. Bamba M, Kawaguchi YW, Tsuchimatsu T (2018) Plant adaptation and speciation studied by population genomic approaches. Developement, Growth \& Differentiation 1-13. Doi: 10.1111/dgd.12578

3. Booth TH (2012) Eucalypts and Their Potential for Invasiveness Particularly in Frost-Prone Regions. International Journal of Forestry Research, doi:10.1155/2012/837165

Page 7/17 
4. Bouvet J-M, Makouanzi Ekomono CG, Brendel O, Laclau J-P, Bouillet J-P, Epron D (2020) Selecting for water use efficiency, wood chemical traits and biomass with genomics selection in a Eucalyptus breeding program. Forest Ecology and Management 465: 118092. Doi.org/10.1016/j.foreco.2020.118092

5. Bradshav WE and Christina M (2006) Evolutionary response to rapid climate change. Holzapfel Science 312 (5779): $1477-$ 1478.

6. Brezard JM (1982) Les eucalyptus introduits au Congo 1953-1981. Note interne CTFT, Pointe-Noire, 100p.

7. Cossalter C, Vigneron Ph, Brooker MIH (1999) Eucalyptus d'Australie. Habitats naturels et dynamique d'évolution. Le Flamboyant $49: 15-20$.

8. Díaz S, Cabido M, Casanoves F (1998) Plant functional traits and environmental filters at a regional scale. J. Veg. Sci. 9:113-122.

9. Díaz S, Hodgson JG, Thompson K, Cabido M, Cornelissen JHC, Jalili A, Montserrat-Martí G, Grime JP, Zarrinkamar F, Asri Y, Band SR, Basconcelo S, Castro-Díez P, Funes G, Hamzehee B, Khoshnevi M, Pérez-Harguindeguy N, Pérez-Rontomé MC, Shirvany FA, Vendramini F, Yazdani S, Abbas-Azimi R, Bogaard A, Boustani S, Charles M, Dehghan M, de Torres-Espuny L, Falczuk V, Guerrero-Campo J, Hynd A, Jones G, Kowsary E, Kazemi-Saeed F, Maestro-Martínez M, Romo-Díez A, Shaw S, Siavash B, Villar-Salvador P, Zak MR (2004) The plant traits that drive ecosystems: evidence from three continents. J. Veg. Sci. 15:295-304.

10. Dillon S, McEvoy R, Baldwin DS, Rees GN, Parsons Y, Southerton S (2014) Characterisation of Adaptive Genetic Diversity in Environmentally Contrasted Populations of Eucalyptus camaldulensis Dehnh. (River Red Gum). PLoS ONE 9(8): e103515. Doi: 10.1371/journal.pone.0103515

11. Drenovsky RE, Grewell BJ, D’Antonio CM, Funk JL, James JJ, Molinari N, Parker IM and Richards CL (2012) A functional trait perspective on plant invasion. Annals of Botany 110 (1): 141-153.

12. El-Lakany MH, El-Osta ML, Badran AO (1980) Evaluation of newly introduced Eucalyptus camaldulensis provenances in Egypt. Alexandria Jounral of Agricutural Research 28: 309-319.

13. Epron D, Bonal D, Brendel O, Roupsard O, Ponton S, Dreyer E (2007) L'approche isotopique : une méthode d'investigation puissante de l'acquisition et de l'utilisation de l'eau par les plantes. L'eau en horticulture : Economiser maintenant $9 \mathrm{e}$ colloque du conseil scientifique de la SNHF, 3p. www.SNHF.org

14. Evans LT, Wardlaw IF, King RW (1985) Plants and environment: two decades of research at the canberra phytotron. Botanical review 51 (2): 203-272.

15. FAO (2014) Global Plan of Action for the Conservation, Sustainable Use and Development of Forest Genetic Resources. Rome, 31p. http://www.fao.org/3/a-i3849e.pdf

16. FAO (2015) Coping with climate change - the roles of genetics resources for food and agriculture. Rome, 130p.

17. Franks SJ and Hoffmann AA (2012) Genetics of climate change adaptation. Annu. Rev. Genet. 46: 185-208.

18. Gardner A (2017) The purpose of adaptation. Interface Focus 7: 20170005.http://dx.doi.org/10.1098/rsfs.2017.0005

19. Grime JP (1977) Evidence for the existence of three primary strategies in plants and its relevance to ecological and evolutionary theory. Am Nat 111:1169-1195.

20. Groulez J (1964) Introduction d'eucalyptus au Congo Brazzaville. Bois et Forêts des Tropiques 93: 3-14.

21. Hamrick JL (2004) Response of forest trees to global environmental changes. Forest Ecology Management 197(1-3): 323335.

22. Hereford J (2009) A quantitative survey of local adaptation and fitness trade-offs. Am. Nat. 173:579-88.

23. Hunde T, Belachew Gizachew B and Harwood C (2007) Genetic variation in survival and growth of Eucalyptus globulus ssp. globulus in Ethiopia. Australian Forestry 70 (1): 48-52.

24. James S, Bell D (1995) Morphology and Anatomy of Leaves of Eucalyptus camaldulensis Clones: Variation Between Geographically Separated Locations. Aust. J. Bot. 43: 415-433.

25. Jamet R, Rieffel JM (1976) Carte pédologique du Congo à 1/200.000, feuille Pointe-Noire, feuille Loubomo, notice d'exploitation ${ }^{\circ} 65$, ORSTOM, Paris. 
26. Jump AS and Peñuelas J (2005) Running to stand still: Adaptation and the response of plants to rapid climate change. Ecology Letters 8: 1010-1020.

27. Kawecki TJ, Ebert D (2004) Conceptual issues in local adaptation. Ecology Letters 7: 1225-1241.

28. Killi D, Bussotti F, Raschi A and Haworth M (2017) Adaptation to high temperature mitigates the impact of water deficit during combined heat and drought stress in C3 sunflower and C4 maize varieties with contrasting drought tolerance. Physiol. Plant. 159 (2): 130-147. Doi: 10.1111/ppl.12490

29. Kremer A (2000) Changements climatiques et diversité génétique. Revue Forestière Française, LII: 91-98.

30. Laclau J-P, Gay F, Bouillet J-P, Bouvet J-M, Chaix G, Clément-Demange A, Do F, Epron D, Favreau B, Gion J-M, Nouvellon Y, Pujade-Renaud V, Thaler P, Verhaegen D and Vigneron Ph (2016) Adaptation and Mitigation in Tropical Tree Plantations. In Climate Change and Agriculture Worldwide, Éditions Quæ E. Torquebiau (ed.). Doi : 10.1007/978-94-017-7462-8_15

31. Lambers H, Poorter H (1992) Inherent variation in growth rate between higher plants: a search for physiological causes and ecological consequences. Advances in Ecological Research 23 : 187-261.

32. Lavorel S, Garnier E (2002) Predicting changes in community composition and ecosystem functioning from plant traits: revisiting the Holy Grail. Funct. Ecol. 16:545-556.

33. Leimu R, Fischer M (2008) A Meta-Analysis of Local Adaptation in Plants. PLoS ONE 3(12): e4010. Doi: 10.1371/journal.pone.0004010

34. Lemcoff JH, Guarnaschelli AB, Garau AM, Prystupa P (2002) Elastic and osmotic adjustments in rooted cuttings of several clones of Eucalyptus camaldulensis Dehnh. from southeastern Australia after a drought. Flora - Morphology, Distribution, Functional Ecology of Plants 197: 134-142.

35. Liu M, Wang Z, Li S, Lu X, Wang X and Han X (2017) Changes in specific leaf area of dominant plants in temperate grasslands along a 2500-km transect in northern China. Scientific Reports 7 : 10780. Doi:10.1038/s41598-017-11133-z

36. Loo J, Fady B, Dawson I, Vinceti B \& Baldinelli G (2011) Climate change and forest genetic resources: state of knowledge, risks and opportunities. Commission on Genetic Resources for Food and Agriculture. FAO Background Study Paper No.56. FAO, Rome, 29p.

37. Morshet S (1981) Physiological Activity, in a Semiarid Environment, of Eucalyptus camaldulensis Dehn. from Two Provenances. Aust J Bot 29: 97-110.

38. Niinemets Ü (1999) Research review. Components of leaf dry mass per area-thickness and density-alter leaf photosynthetic capacity in reverse directions in woody plants. New Phytologist 144(1): 35-47.

39. Nzila JDD (2001) Caractérisation minéralogique des sols ferralitiques sableux sous plantation d'Eucalyptus et sous savane naturelle de la région de Pointe-Noire (Congo). Rapport UR2PI, Pointe-Noire, 51p.

40. Otegbeye GO (1985) Provenance productivity in Eucalyptus camaldulensis and its implications to genetic improvement in the savanna region of nigeria. Silvae Genetica 121-126.

41. Parmesan C (2006) Ecological and evolutionary responses to recent climate change. Ann. Rev. Ecol. Evol. System 37: 637669.

42. Pérez-Harguindeguy N, Diaz S, Garnier E, Lavorel S, Poorter H, et al. (2013) New handbook for standardised measurement of plant functional traits worldwide. Australian Journal of Botany 61: 167-234.

43. Price TD, Qvarnström A, Irwin DE (2003) The role of phenotypic plasticity in driving genetic evolution. Proc. Royal Soc. Lond. Ser. B 270:1433-1440.

44. Reich PB, Wright IJ, Cavender-Bares J, Craine JM, Oleksyn J, Westoby M, Walters MB (2003) The evolution of plant functional variation: traits, spectra, and strategies. International Journal of Plant Sciences 164(S3): S143-S164.

45. Savolainen O, Lascoux M and Merilä J (2013) Ecological genomics of local adaptation. Nature Reviews | Genetics 14: 807820. Doi: $10.1038 / \mathrm{nrg} 3522$

46. Scheepens JF, Frei ES, Stöcklins J (2010) Genotypic and environmental variation in specific leaf area in a widespread Alpine plant after transplantation to different altitudes. Oecologia 164:141-150. Doi: 10.1007/s00442-010-1650-0 
47. Sefton CA, Montagu K, Atwell BJ, Conroy JP (2002) Anatomical variation in juvenile eucalypt leaves accounts for differences in specific leaf area and CO2 assimilation rates. Austrian Journal of Botany 50: 301-310.

48. Steane DA, Mclean EH, Potts BM, Prober SM, Stock WD, Stylianou VM, Vaillancourt RE and Byrne M (2017) Evidence for adaptation and acclimation in a widespread eucalypt of semi-arid Australia. Biological Journal of the Linnean Society $121: 484-500$.

49. Thumma BR, Sharma N, Southerton SG (2012) Transcriptome sequencing of Eucalyptus camaldulensis seedlings subjected to water stress reveals functional single nucleotide polymorphisms and genes under selection. BMC Genomics 13 : 364, http://www.biomedcentral.com/1471-2164/13/364

50. Vandewalle M, de Bello F, Berg MP, Bolger T, Dolédec S, Dubs F, Feld CK, Harrington R, Harrison PA, Lavorel S, da Silva PM, Moretti M, Niemela J, Santos P, Sattler T, Sousa JP, Sykes MT, Vanbergen AJ, Woodcock BA (2010) Functional traits as indicators of biodiversity response to land use changes across ecosystems and organisms. Biodiversity Conservation 19: 2921-2947.

51. VanWallendael A, Soltani A, Emery NC, Peixoto MM, Olsen J and Lowry DB (2019) A Molecular View of Plant Local Adaptation: Incorporating Stress-Response Networks. Annu. Rev. Plant Biol. 70: 559-83.

52. Vile D, Garnier E, Shipley B, Laurent G, Navas ML, Roumet C and Midgley G. F., 2005. Specific leaf area and dry matter content estimate thickness in laminar leaves. Annals of botany 96(6): 1129-1136.

53. Westoby M., Falstr D.S., Moles A.T., Vesk P.A., Wright I.J., 2002. Plant ecological strategies: some leading dimensions of variation between species. Annual Review of Ecology and Systematic, 33: 125-159.

54. Wright IJ, Reich PB, Westoboty M, Ackerly DD, Baruch Z et al. (2004) The worldwide leaf economics spectrum. Nature 428 (6985) : 821-827.

55. Wright SJ, Zhou DC, Kuhle A and Olsen KM (2018) Continent-wide climatic variation drives local adaptation in north american white clover. Journal of Heredity 109(1) : 78-89. Doi : 10.1093/jhered/esx060

\section{Tables}


Table 1

List of species study and their belonging subgenus

\begin{tabular}{|c|c|c|c|c|c|}
\hline Specie code & Subgenus & Specie & Specie code & Subgenus & Specie \\
\hline 1 & Alveolata & E. microcorys & 16 & \multirow[t]{18}{*}{ Symphyomyrtus } & E. alba_Australie \\
\hline 2 & Blakella & E. tesselaris & 17 & & E. alba_Timor \\
\hline 3 & \multirow[t]{6}{*}{ Corymbia } & E. citriodora & 18 & & E. apodophylla \\
\hline 4 & & E. maculata & 19 & & E. bigalerita \\
\hline 5 & & E. nesophila & 20 & & E. brassiana \\
\hline 6 & & E. peltata & 21 & & E. exserta \\
\hline 7 & & E. polycarpa & 22 & & E. grandis \\
\hline 8 & & E. torelliana & 23 & & E. paniculata \\
\hline 9 & \multirow[t]{4}{*}{ Eucalyptus } & E. acmenoides & 24 & & E. pellita \\
\hline 10 & & E. phaeotricha & 25 & & E. propinqua \\
\hline 11 & & E. pilularis & 26 & & E. punctata \\
\hline 12 & & E. umbra & 27 & & E. resinifera \\
\hline 13 & Eudesmia & E. tetrodonta & 28 & & E. robusta \\
\hline \multirow[t]{2}{*}{14} & Idiogenes & E. cloeziana & 29 & & E. tereticornis \\
\hline & Minutifructu & & & & \\
\hline \multirow[t]{3}{*}{15} & & E. raveretiana & 30 & & E. urophylla_Alor \\
\hline & & & 31 & & E. urophylla_Flores \\
\hline & & & 32 & & E. urophylla_Timor \\
\hline
\end{tabular}

Table 2

Descriptive statistics and Anova results

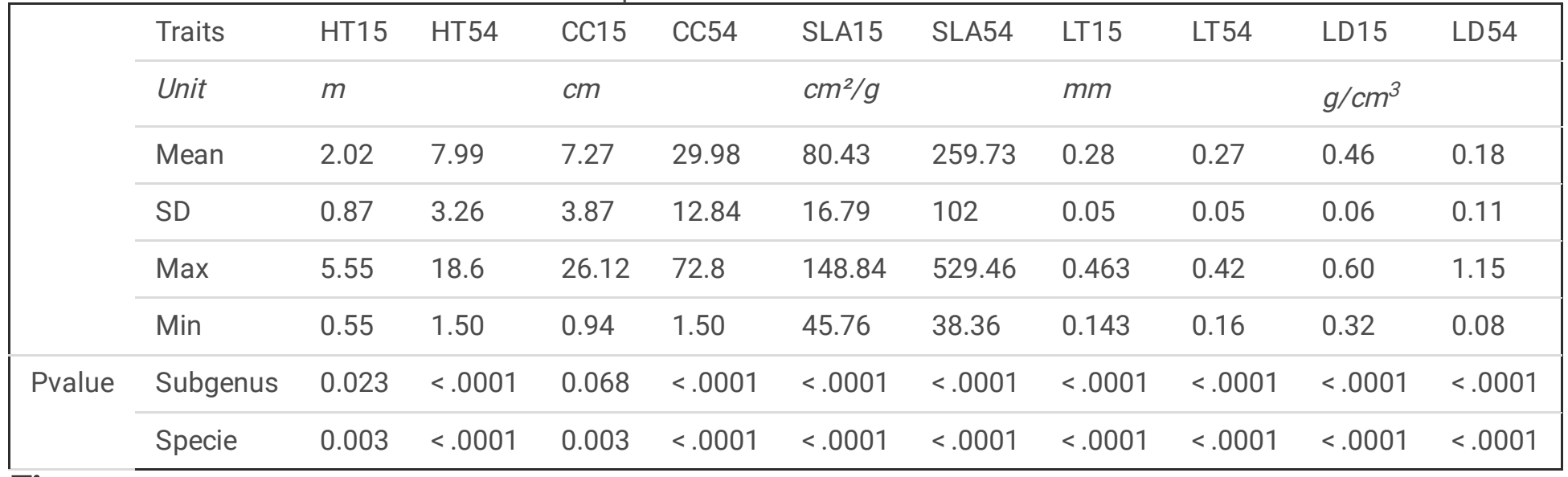

\section{Figures}




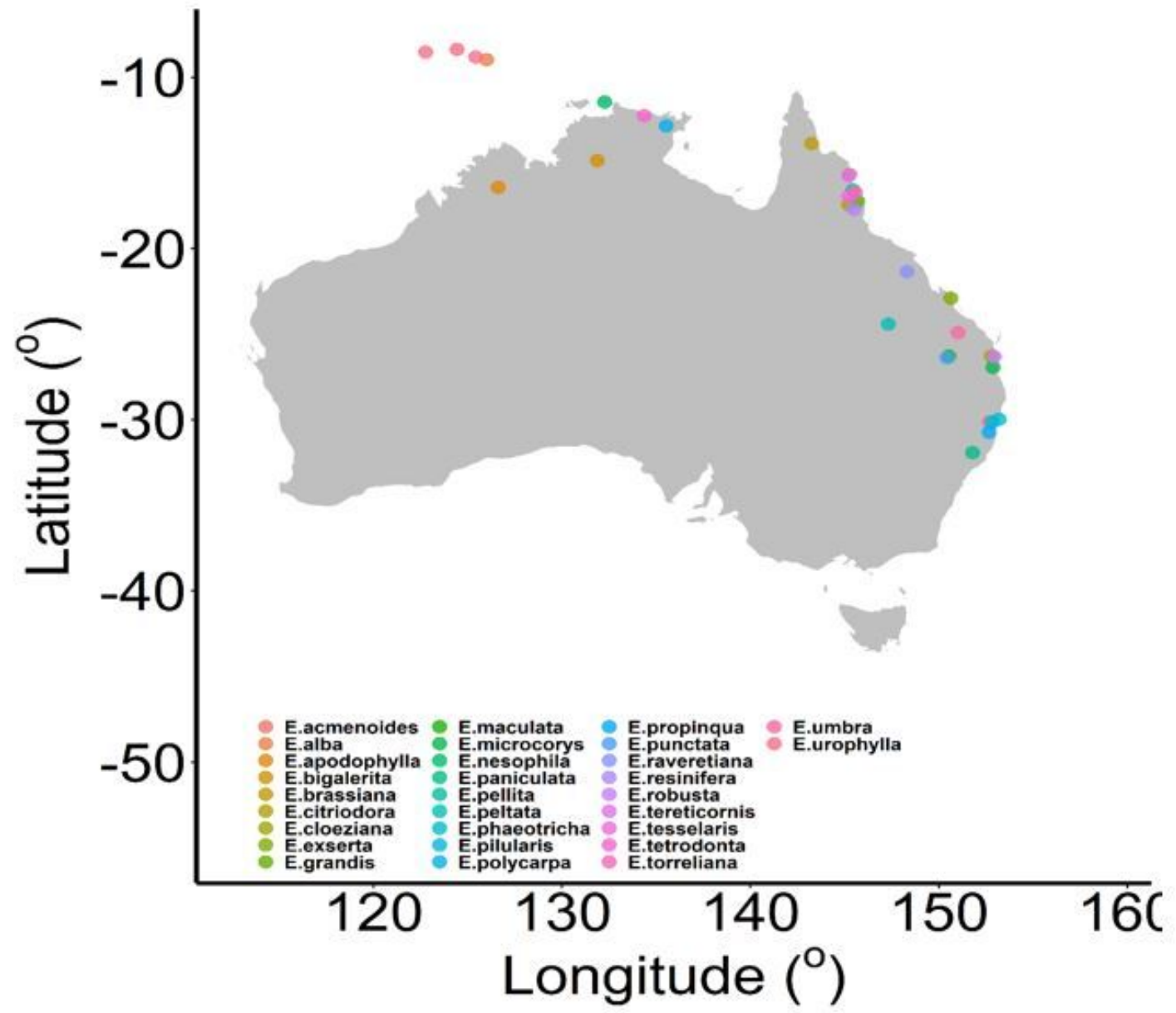

Figure 1

Location of harvesting areas for the studied species 


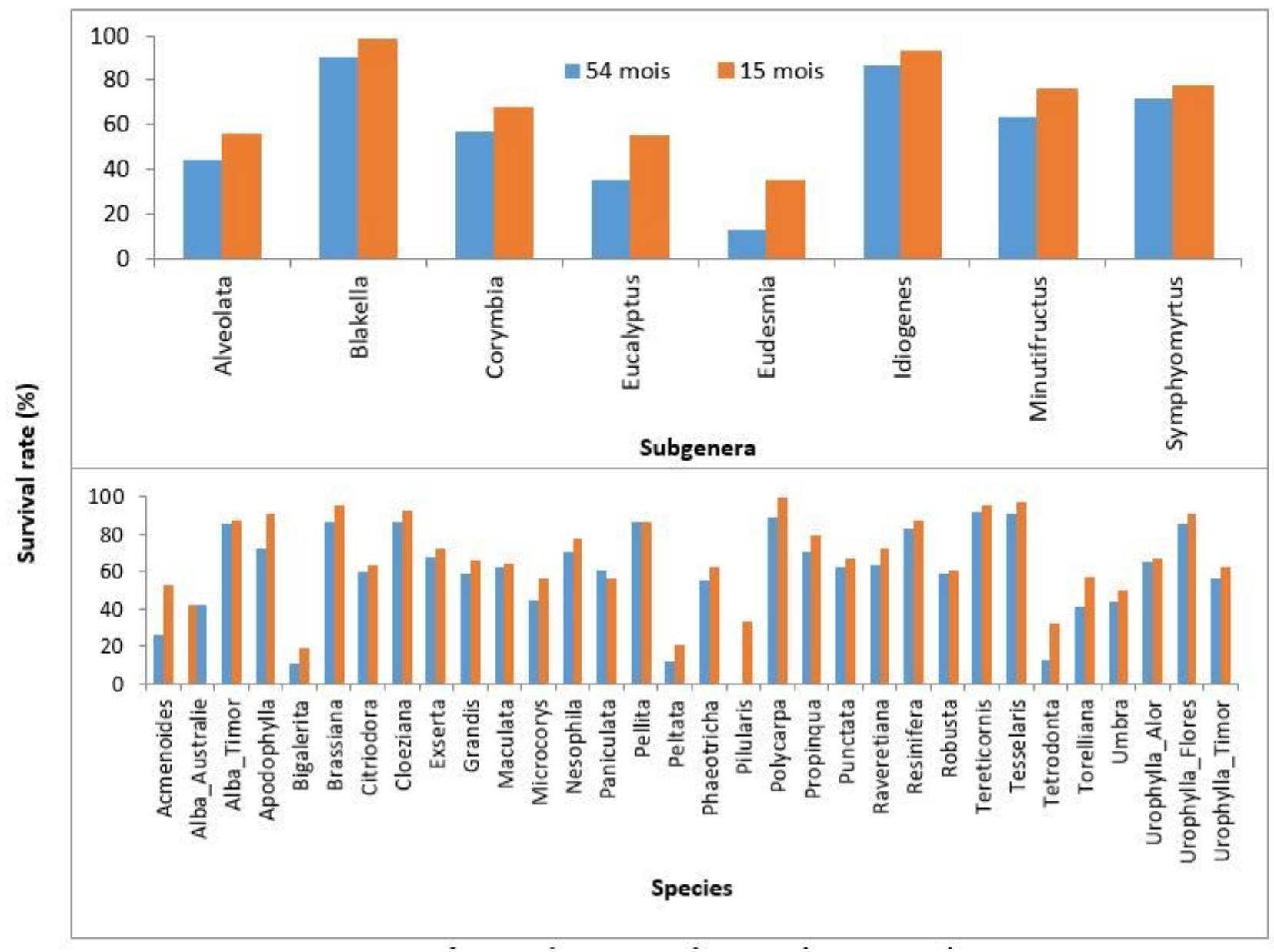

Figure 2

Mean of survival rate according to subgenera and species 


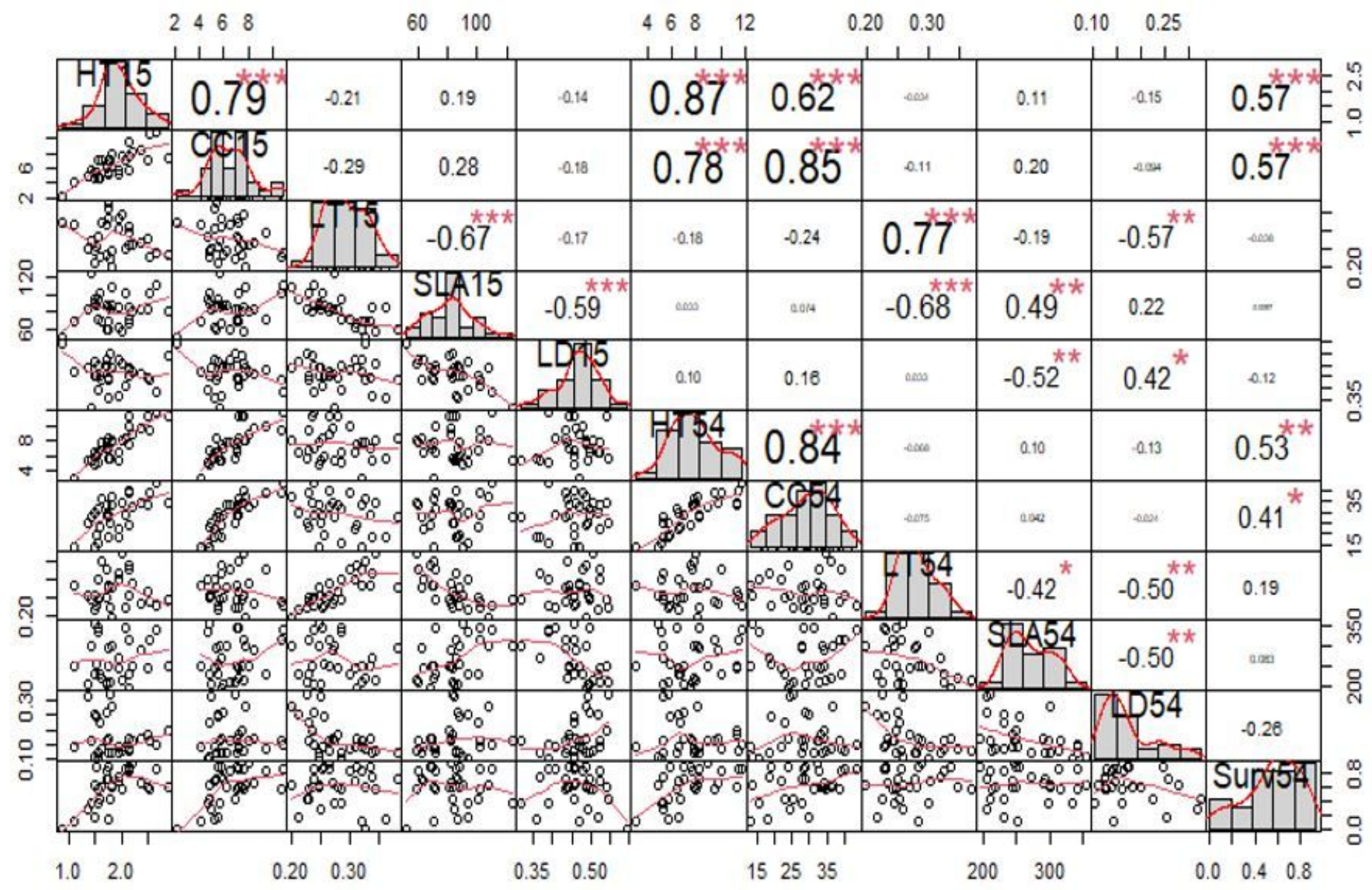

Figure 3

Between traits and juvenile-adult correlations 


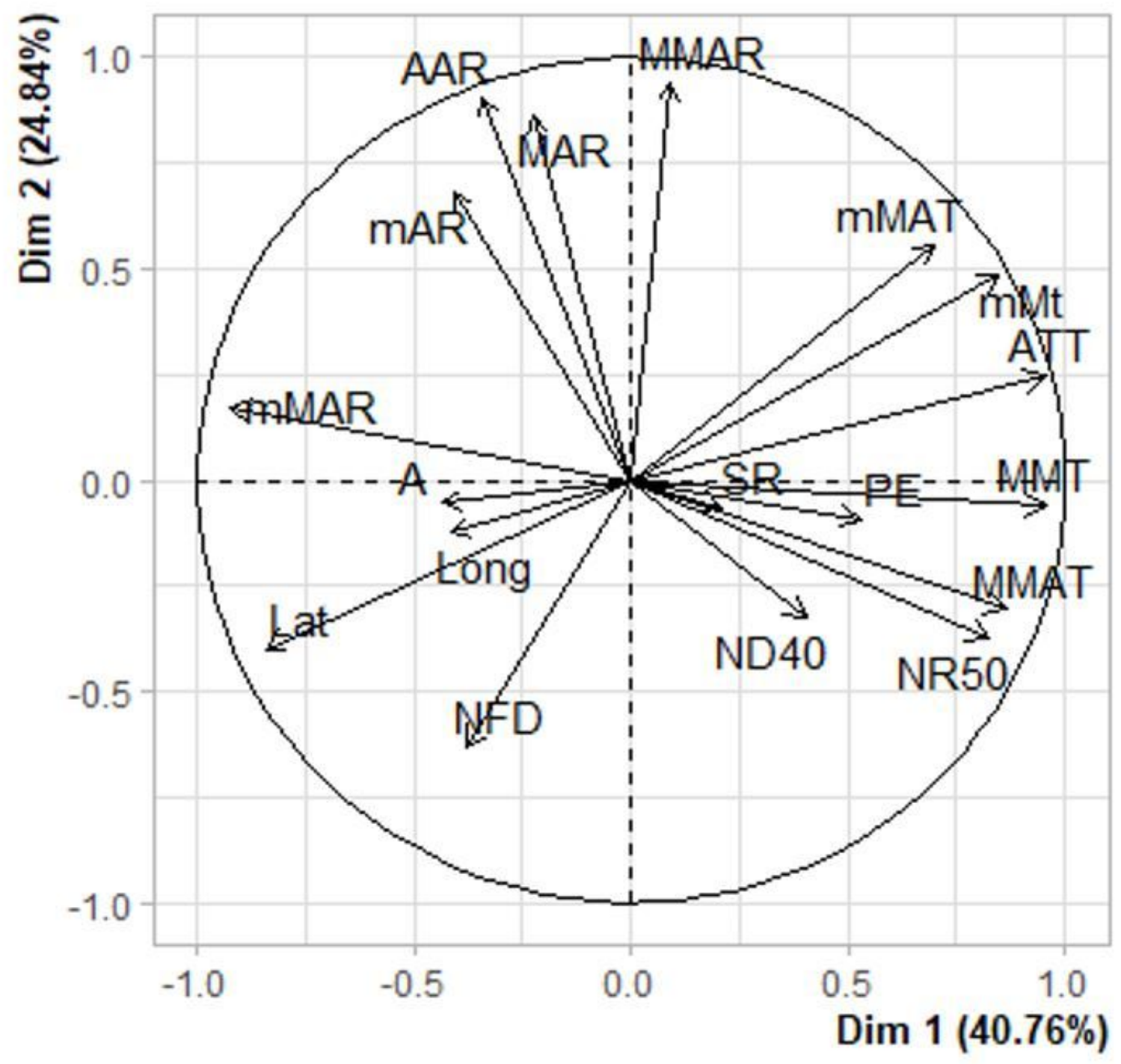

Figure 4

PCA graph of variables 


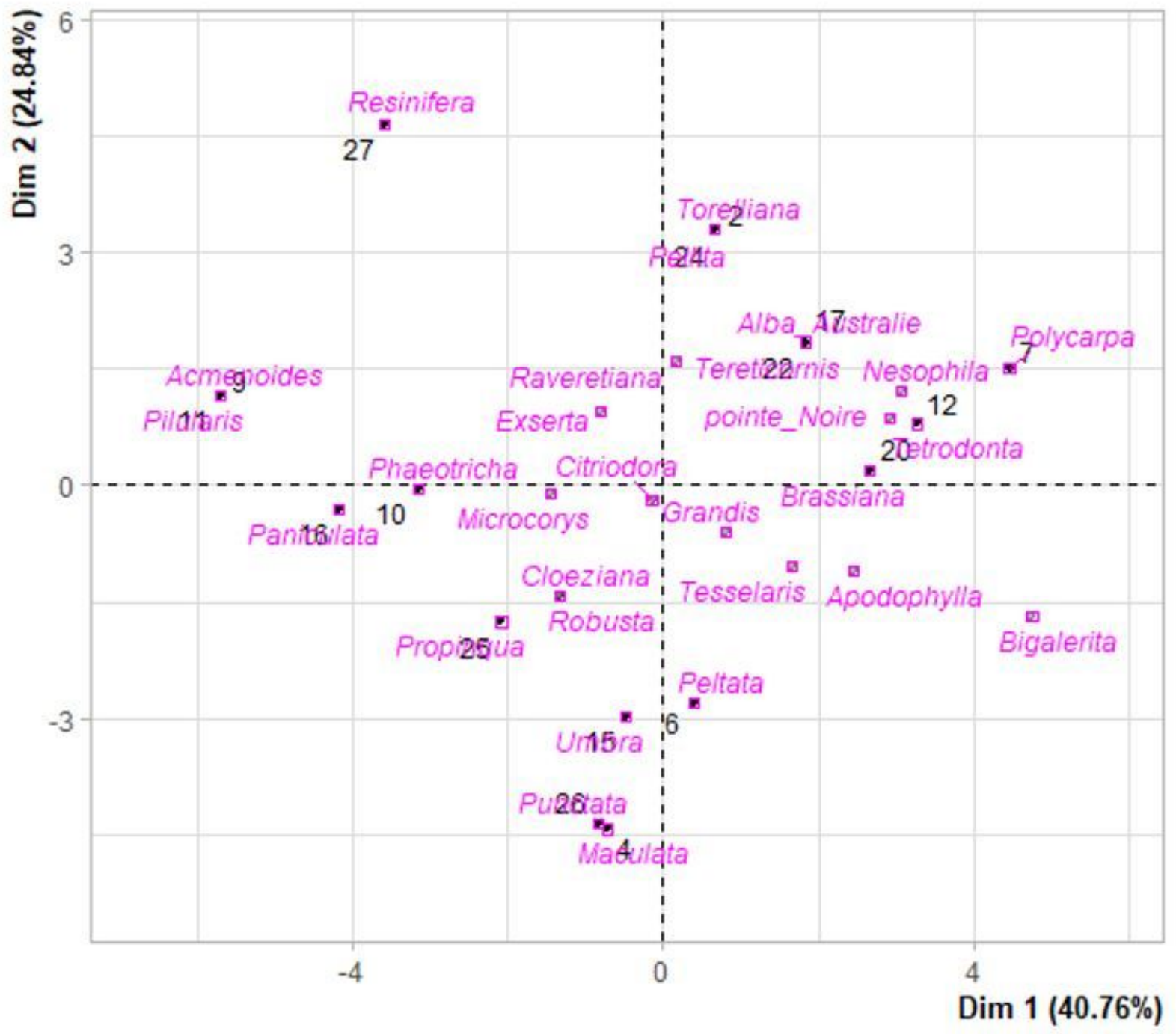

Figure 5

PCA graph of individuals 


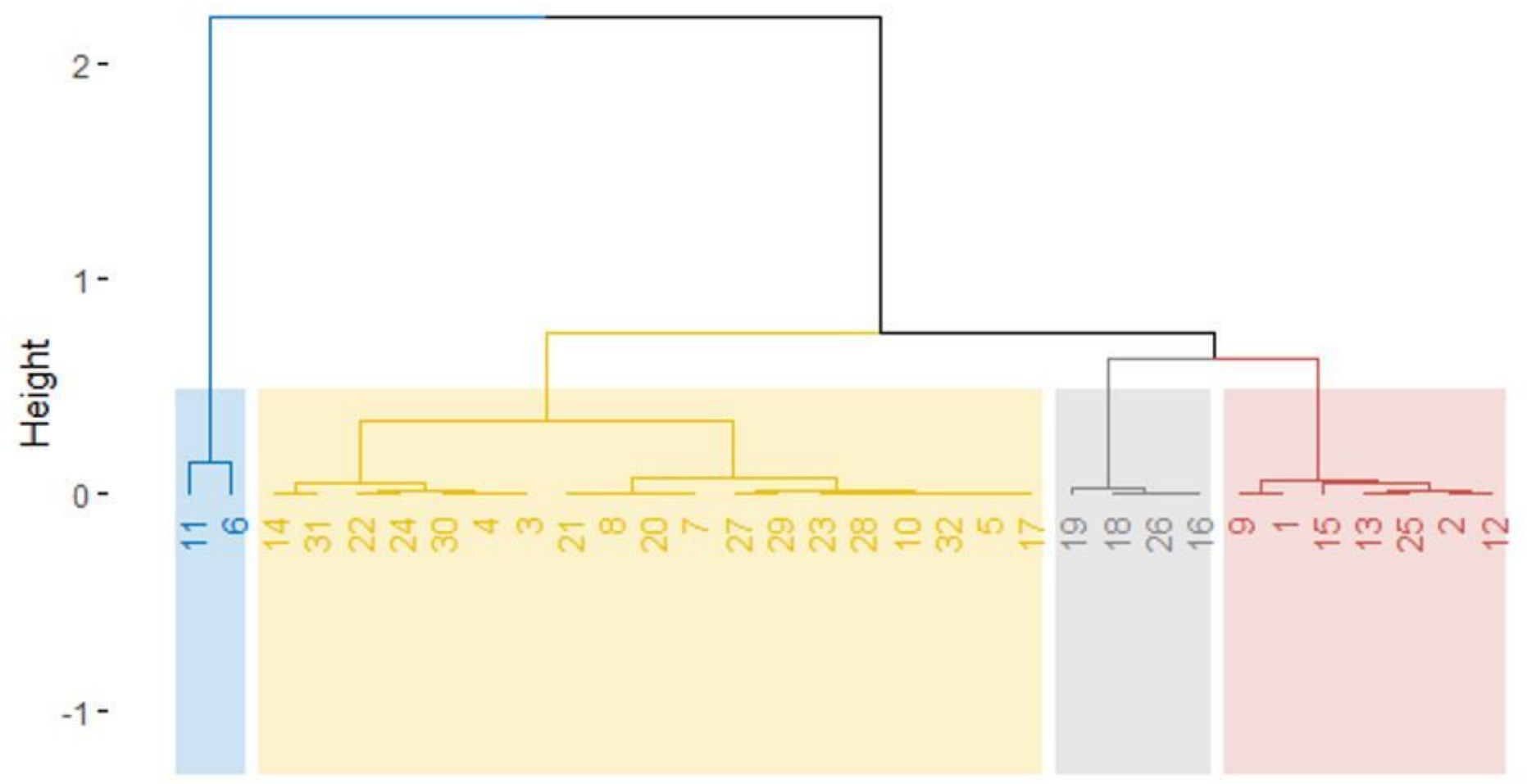

\section{Figure 6}

Cluster dendogram of species Cluster 1 : 11- E.pilularis, 6- E.peltata ; Cluster 2 : 14- E.cloeziana, 31- E.urophylla_Flores, 22E.grandis, 24- E.peilita, 30- E.urophylla_Alor, 4- E.maculata, 3- E.citriodora, 21- E.exserta, 8- E.torelliana, 20- E.brassiana, 7E.polycarpa, 27- E.resinifera, 29- E.tereticornis, 23- E.paniculata, 28- E.robusta, 10- E.phaeotricha, 32- E.urophylla_Timor, 5E.nesophila, 17- E.alba_Timor ; Cluster 3 : 19- E.bigalerita, 18- E.apodophylla, 26- E.punctata, 16- E.alba_Australie ; Cluster 4 : 9 E.acmenoides, 1- E.microcorys, 15- E.raveretiana, 13- E.tetrodonta, 25- E.propinqua, 2- E.tesselaris, 12- E.umbra.

\section{Supplementary Files}

This is a list of supplementary files associated with this preprint. Click to download.

- Supplementarymaterial.docx

- Supplementarymaterial.docx 